\title{
CURRENT LITERATURE ON PERCEPTION, PERFORMANCE, AND EXPERIMENTAL SOCIAL PSYCHOLOGY
}

Citations of current literature are arranged in outline form so that readers may easily find the particular articles in which they are interested. The literature on Human Experimental Psychology is divided into two parts, with each part appearing in alternate months. The part covered here consists of Perception, Performance, and Experimental Social Psychology. The part to be published next month will consist of citations on Human Memory, Learning, and Thinking. The principal headings used are given on the cover along with page references.

\section{METHODS AND INSTRUMENTATION}

\section{METHODS \& DESIGNS}

ANDERSON, N. H. (Univ. of California, San Diego, La Jolla, Calif. 92037), SAWYERS, B. K., \& FARKAS, A. J. President paragraphs. Behavior Research Methods \& Instrumentation, 1972, 4, 177-192.

BEATTY, W. W. (North Dakota State Univ., Fargo, N. Dak. 58102). How blind is blind? A simple procedure for estimating observer naiveté. Psychological Bulletin, 1972, 78, 70-71.

BROGDEN, H. E. (Purdue Univ., Lafayette, Ind. 47907). Some observations on two methods in psychology. Psychological Bulletin, 1972, 77, 431-437.

BYNNER, J. (Open Univ., Walton Hall, Walton Bletchley, Buckinghamshire, England), \& ROMNEY, D. A method for overcoming the problem of concept-scale interaction in semantic differential research. British Journal of Psychology, 1972, 63, 229-234.

HARRIS, R. J. (Univ. of New Mexico, Albuquerque, N. Mex. 87106). An interval-scale classification system for all $2 \times 2$ games. Behavioral Science, 1972, 17, 371-383.

MACKENZIE, B. D. (Univ. of Edinburgh, 60 Pleasance, Edinburgh 8 , Scotland). Mea suring the strength, structure, and reliability of free associations. Psychological Bulletin, 1972, 77, 438-445.

POSNANSKY, C. J. (Univ. of Colorado, Boulder, Colo. 80302), BATTIG, W. F., \& VOSS, -J. F. A new probe technique for the identification of serial learning processes. Behavior Research Methods \& Instrumentation, 1972, $4,129-132$.

ROSENBROCK, F. (Institut für Arbeitswissenschaft, Univ. of Tech., Darmstadt, German Federal Republic). Hardware problems in ergonomics measurements. Ergonomics, 1971, 14, 617-623.

STOKOLS, D. (Univ, of North Carolina, Chapel Hill, N.C. 27514). On the distinction between density and crowding: Some implications for future research. Psychological Review, 1972, 79, 275-277.
YEN, S. (Essex Community Coll., Essex, Md. 21221), McINTIRE, R. W., \& BERKOWITZ, S. Extinction of inappropriate sleeping behavior: Multiple assessment. Psychological Reports, $1972,30,375-378$.

\section{INSTRUMENTATION} \& TECHNIQUES

CARLSON, K. R. (Dept. of Pharmacol., Univ. of Pittsburgh Sch. of Med., Pittsburgh, Pa. 15213), \& SPALLA, L. J. A system for cutaneous electrical stimulation mimicking touch. Behavior $\mathrm{Research} \quad \mathrm{Methods} \&$ Instrumentation, 1972, 4, 199-200. HARTLEY, L. R. (Med. Rsch. Council, Applied Psychol. Unit, 15 Chaucer Rd., Cambridge, England). A method for storing a program of stimuli and responses on magnetic tape using frequency coding. Psychophysiology, 1972, 9, 380-382.

HENDERSON, A. I. (Univ. of Southampton, Highfield, Southampton, SO9 $5 \mathrm{HH}$, England), \& SMITH, D. G. Editing silent hesitation from speech recordings. Behavior Research Methods \& Instrumentation, 1972, 4, 195-196. KORÁL, V. (Inst. for Hematol. \& Blood Transfusion, Prague, C z e c hos lovakia), \& ŠTEPITA-KLAUČO, M. Linear liquid strain gauge device for medical applications. Activitas Nervosa Superior, 1971, 13, 259-265.

MACPHERSON, L. (Bldg. 4, VA Hosp., 3801 Miranda Ave., Palo Alto, Calif. 94305), \& KOPELL, B. $S$. A zero-setter and voltage reference unit for EEG amplifier systems. Psychophysiology, 1972, $9,262-265$.

RUGH, J. D. (Univ. of California, Santa Barbara, Calif. 93106), \& SOLBERG, W. K. The measurement of human oral forces. Behavior $\mathrm{R}$ esearch Methods \& Instrumentation, 1972, 4, 125-128. WOODARD, W. T. (Univ, of South Florida, Tampa, Fla. 33620). A logarithmic electronic integrator for activity transducers. Behavior $\mathrm{R}$ e search Methods \& Instrumentation, 1972, 4, 149-150.
WRIGHT, A. A. (Univ. of Texas, Austin, Tex. 78712). Construct a monochromator from a single interference filter. Journal of the Experimental Analysis of Behavior, $1972,18,61-63$.

\section{STATISTICAL TECHNIQUES}

CICCHETTI, D. V. (VA Hosp., West Haven, Conn. 06516). Extension of multiple-range tests to interaction tables in the analysis of variance: A rapid approximate solution. Psychological Bulletin, 1972, 77, 405-408.

DAVIDSON, M. L. (Univ. of Rochester, Rochester, N.Y. 14627). Univariate versus multivariate tests in repeated-measures experiments. Psychological Bulletin, 1972, 77, 446.452.

HINTZMAN, D. L. (Univ. of Oregon, Eugene, Oreg. 97403). On testing the independence of associations. Psychological Review, 1972, 79, 261-264.

LAURIG, W. (Institut für Arbeitswissenschaft, Univ. of Tech., Darmstadt, German Federal Republic), BECKER-BISKABORN, G.-U., \& REICHE, D. Software problems in analysing physiological and work study data. Ergonomics, 1971, 14, 625-631.

LYKKEN, D. T. (Psychiat. Rsch. Unit, Box 392 Mayo, Univ. of Minnesota, Minneapolis, Minn. 55455). Range correction applied to heart rate and GSR data. Psychophysiology, 1972, 9, 373-379.

MARTIN, E. (Human Perf. Ctr., 330 Packard Rd., Ann Arbor, Mich. 48104), \& GREENO, J. G. Independence of associations tested: A reply to D. L. Hintzman. Psychological Review, 1972, 79, 265-267.

MIRKIN, B. G. (Inst. of Economics, Siberian Div. of Acad. of Sci., Novosibirsk, U.S.S.R.). Description of some relations on the set of real-line intervals. Journal of Mathematical Psychology, 1972, 9, 243-252.

SCHMIDT, R. A. (Dept. of Physical Ed., Univ. of Michigan, Ann Arbor, Mich. 48104). The index of preprogramming (IP): A statistical method for evaluating the role of feedback in simple movements. Psychonomic Science, 1972, 27, 83-85. 
TITIEV, R. J. (Stanford Univ., Stanford, Calif. 94305). Measurement structures in classes that are not universally axiomatizable. Journal of Mathematical Psychology, 1972, 9, 200-205.

VIKIS-FREIBERGS, V. (Univ. of Montreal, Montreal 101, P.Q., Canada). A stochastic model for free association response hierarchies? Psychological Review, 1972, 79, 268-274.

WEISS, D. J. (Calif. State Coll., Los Angeles, Calif. 90032), \& ANDERSON, N. H. Use of rank order data in functional measurement. Psychological Bulletin, 1972, 78, 64-69.

\section{COMPUTER TECHNOLOGY}

DUNLAP, W. P. (Tulane Univ., New Orleans, La. 70118). Three subroutines for dealing efficiently with permutations. Behavior $\mathrm{Research} M$ e thods \& Instrumentation, 1972, 4, 159-160.

DURELL, A. B. (Ontario Inst. for Studies in Ed., Toronto, Ont., C a n a d a). P a i n l e s s c o m put e r c ontrolled experimentation. Behavior Research Methods \& Instrumentation, 1972, 4, 165-166.

FLANAGAN, J. L. (Bell Tel. Labs., Murray Hill, N.J. 07974). Voices of men and machines. Journal of the Acoustical Society of America, 1972, 51, 1375-1387.

HAYES-ROTH, F. (Univ, of Michigan, Ann Arbor, Mich. 48104), \& LONGABAUGH, R. REACT: A tool for the analysis of complex transitional behavior matrices. Behavioral Science, 1972, 17 , 384-394.

HUBBARD, A. E. (Electrical Eng.
Dept., Univ. of Wisconsin, Madison, Wis. 53706), \& GEISLER, C. D. A hybrid-computer model of the cochlear partition. Journal of the Acoustical Society of America, 1972, 51, 1895-1903.

JESTEADT, W. (Bioacoustics Lab., Eye \& Ear Hosp. \& Sch. of Med., Univ. of Pittsburgh, Pittsburgh, $\mathrm{Pa}$. 15213). SNP: A system for nonadaptive procedures. Behavior $\mathrm{R}$ e s e a c h M e thods \& Instrumentation, 1972, 4, 209-213.

LOVELL, J. D. (Percep. Systems Lab., Univ. of California, Los Angeles, Calif. 90024), \& CARTERETTE, E. C. Digital generation of acoustic stimuli. Behavior Research Methods \& Instrumentation, 1972, 4, 151-155.

PELLEGRINO, J. W. (Univ. of Colorado, Boulder, Colo. 80302 ). A FORTRAN IV program for analyzing higher-order subjective organization units in free recall learning. Behavior Research Methods \& Instrumentation, 1972, 4, 215-217.

RAY, W. J., \& HOGGE, J. H. (George Peabody Coll., Nashville, Tenn. 37203). BASIC subroutines for on-line experiments using Hewlett-Packard computers. Behavior Research Methods \& Instrumentation, 1972, 4, 218.

SCHOLZ, K. W. (Indiana Univ., Bloomington, Ind. 47401). Computerized process control in behaviaral science research. Behavior Research Methods \& Instrumentation, 1972, 4, 203-208. STARR, B. J. (Howard Univ., Washington, D.C. 20001). Automated problem solving for the behavioral sciences. Behavior $\mathrm{R}$ esearch $\mathrm{Methods \quad \&}$ Instrumentation, $1972,4,161-164$.

\section{PERCEPTUAL AND SENSORY PROCESSES}

SCOTT, R. (Univ. of Northern Iowa, Cedar Falls, Iowa 50613), \& SATTEL, L. Perception and language: A German replication of the Piaget-Inhelder position. Journal of Genetic Psychology, 1972, 120, 203-210.

\section{GENERAL}

DEREGOWSKI, J. B. (Univ. of Aberdeen, Aberdeen, Scotland AB9 1AS). Reproduction of orientation of Kohs-type figures: A cross-cultural study. British Journal of Psychology, 1972, 63, 283-296.

HANDEL, S. (Univ. of Tennessee, Knoxville, Tenn. 37916), \& IMAI, $S$. The free classification of analyzable and unanalyzable stimuli. Perception \&

Psychophysics, 1972, 12, 108-116. MAYO, P. R. (Sch. of Cultural \& Community Studies, Univ. of Sussex, Sussex, England), \& BELL, J. M. A note on the taxonomy of Witkin's field-independence measures. British Journal of Psychology, 1972, 63, 255-256.

MILLAR, S. (Dept. of Exptl. Psychol., Univ. of Oxford, Oxford, England). The development of visual and kinaesthetic judgements of distance. British Journal of Psychology, 1972, 63, 271-282.

MO, S. S. (Univ. of Detroit, Detroit, Mich. 48221), \& MICHALSKI, V. A. Judgment of temporal duration of area as a function of stimulus configuration. Psychonomic Science, 1972, 27, 97-98.
MO, S. S. (Univ, of Detroit, Detroit, Mich. 48221), \& MICHALSKI, V A. Non-monotonicity of temporal recognition of brief duration. Perceptual \& Motor Skills, 1972, 34, 887-890.

RUDNICK, M. (Day Care Ctr., Univ. of Colorado Med. Ctr., Denver, Colo. 80220), MARTIN, V., \& STERRITT, G. M. On the relative difficulty of auditory and visual, temporal and spatial, integrative and nonintegrative sequential pattern comparisons. Psychonomic Science, 1972, 27, 207-210.

TEGHTSOONIAN, M. (Clark Sci. Ctr., Smith Coll., Northampton, Mass. 01060). Apparent length as a function of tilt does not depend on orientation of the standard. Journal of Experimental Psychology, 1972, 94, 191-197.

\section{Illusions}

BECKER, J. A. (Thomas More Coll., Ft. Mitchell, Ky. 41017). Division and orientation in the vertical-horizontal illusion. Perceptual \& Motor Skills, 1972, 34, 899-902.

FRISBY, J. P. (Univ. of Sheffield, Sheffield, England). The effect of stimulus orientation on the phi phenomenon. Vision Research, $1972,12,1145-1166$.

FRITH, C. D. (Inst. of Psychiat., London Univ., London, England), \& FRITH, U. The solitaire illusion: An illusion of numerosity. Perception \& Psychophysics, 1972, 11, 409-410.

McDONNELL, P. M. (Univ. of New Brunswick, Fredericton, N.B., Canada), \& DUFFETT, J. Vision and touch: $A$ reconsideration of conflict between the two senses. Canadian Journal of Psychology, 1972, 26, 171-180.

PRESSEY, A. W. (Univ. of Manitoba, Winnipeg 19, Man., Canada), \& SWEENEY, $O$. Acute angles and the Poggendorff illusion. Quarterly Journal of Experimental Psychology, 1972, 24,169-174.
RAINVILLE, R. E. (Univ. of New Hampshire, Durham, N.H. 03824), \& DUSEK, V. Euclidean and non-euclidean illusions. Perceptual \& Motor Skills, 1972, 34, 916.

\section{Aftereffects}

BANKS, W. P. (Pomona Coll., Claremont, Calif. 91711), \& KANE, D. A. Discontinuity of seen motion reduces the visual motion aftereffect. Perception \& Psychophysics, 1972, 12, 69-72.

HERSEN, M. (VA Ctr., Jackson, Miss. 39216), LEVINE, J., \& CHURCH, A. Parameters of the spiral after-effect in organics, schizophrenics, and normals. Journal of Genetic Psychology, 
$1972,120,177-187$.

HIRSCH, J. (Columbia Univ., New York, N.Y, 10027), \& MURCH, G. $M$. Variation in hue of a contour-contingent aftereffect due to color adaptation during inspection of the stimulus patterns. Perception \& Psychophysics, 1972, $11,406-408$

MAYHEW, J. E. W. (Univ. of Bristol, Bristol BS8 1HH, England), \& ANSTIS, S. M. Movement aftereffects contingent on color, intensity, and pattern. Perception \& Psychophysics, 1972, 12, 77-85.

\section{Psychophysics}

BROWN, A. L. (Children's Rsch. Ctr., Univ. of Illinois, Champaign, Ill. 61820), SCOTT, K. G., \& URBANO, R. C. Psychophysically scaled cue differences, learning rate, and attentional strategies in a tactile discrimination task. Journal of Experimental Child Psychology, $1972,13,283-302$.

CLARK, B. (San Jose State Coll., San Jose, Calif. 95114), \& STEWART, J. D. The power law for the perception of rotation by airline pilots. Perception \& Psychophysics, $1972,11,433-436$.

DANEV, S. G. (Netherlands Inst. for Preventive Med. TNO, Leiden, The Netherlands), de WINTER, C. R., \& WAR TNA, G. F. Information processing and psychophysiological functions in a task with and without time stress. Activitas Nervosa Superior, 1972, 14, 8-12.

HALL, D. E. (Elmhurst Coll., Elmhurst, Ill. 60126), FUCCI, D. J., \& ARNST, D. J. Vibrotactile stimulation: An investigation of psychophysical methods for establishing threshold. Perceptual \& Motor Skills, 1972, 34, 891-898.

HOUTGAST, T. (Inst. for Percep. RVO-TNO, Soesterberg, The Netherlands). Psychophysical evidence for lateral inhibition in hearing. Journal of the Acoustical Society of America, 1972, 51, 1885-1894.

MARKS, L, E. (John B. Pierce Fdtn. Lab., 290 Congress Ave., New Haven, Conn. 06519), \& CAIN, W. S. Perception of intervals and magnitudes for three prothetic continua. Journal of Experimental Psychology, 1972, 94, 6-17.

MASTERS, H. G. (Juniata Coll., Huntingdon, $\mathrm{Pa}$. 16652), \& PODGORSKI, C. Perception by cebus monkeys: I. Psychophysical judgments of minimal cylindrical volume differences by nonhuman and human subjects. Psychonomic Science, 1972, 28, 1-4.

SCHNEIDER, B. (Columbia Univ., New York, N.Y. 10027), WRIGHT, A. A., EDELHEIT, W., HOCK, P., \&
HUMPHREY, C. Equal loudness contours derived from sensory magnitude judgments. Journal of the Acoustical Society of America, 1972, 51, 1951-1959.

SIEGEL, W. (Univ. of Western Ontario, London 72, Ont., Canada). Memory effects in the method of absolute judgment. Journal of Experimental Psychology, 1972, 94, 121-131.

TERMAN, M. (Northeastern Univ., Boston, Mass. 02115), \& TERMAN $J$. S. Concurrent variation of response bias and sensitivity in an operant-psychophysical test. Perception \& Psychophysics, 1972, $11,428-432$.

WARD, L. M. (Livingston Coll., Rutgers Univ., New Brunswick, N.J. 08903). Category judgments of loudnesses in the absence of an experimenter-induced identification function: Sequential effects and power-function fit. Journal of Experimental Psychology, 1972, 94, 179-184.

\section{Magnitude Estimation}

KRANTZ, D. H. (Univ. of Michigan, Ann Arbor, Mich. 48104). A theory of magnitude estimation and cross-modality matching. Journal of Mathematical Psychology, 1972, 9, 168-199.

SCHNEIDER, B. A. (Columbia Univ., New York, N.Y. 10027), NEURINGER, A. J., \& RAMSEY, D. Magnitude estimation of loudness with a minimum 24-h interstimulus interval. Psychonomic Science, 1972, 27, 243-245.

\section{Signal Detection}

GAUSSIN, J. (Centre de Psychologie Expérimentale et Comparée, B-3041, Pellenberg, Belgium), \& HUPET, B. An experimental validation of the signal detection theory for active touch. Psychonomic Science, 1972, 27, 339-341.

HEATH, R. A. (McMaster Univ., Hamilton, Ont., Canada). A note on channel uncertainty in multidimensional signal detection tasks. Psychonomic Science, 1972, 27, 111-113.

PAUL, D. D. (Biomed. Rsch., New York State Dept. of Mental Hygiene, 722 W. 168th St., New York, N.Y. 10032), \& SUTTON, S. Evoked potential correlates of response criterion in auditory signal detection. Science, 1972, 177 , 362-364.

SORKIN, R. D. (Purdue Univ., Lafayette, Ind. 47907), PASTORE, R. E., \& POHLMANN, L. D. Simultaneous two-channel signal detection. II. Correlated and uncorrelated signals. Journal of the
Acoustical Society of America, 1972, 51, 1960-1965.

TYSON, P. D. (Sir George Williams Univ., Montreal 107, P.Q., Canada). Perceptual modification of sensitivity ( $\left.d^{\prime}\right)$ : Modifying temporal resolution by the consistency of the spatial configuration. Perception \& Psychophysics, 1972, 12, 45-49.

YOST, W. A. (Communication Sci. Lab., Univ. of Florida, Gainesville, Fla. 32601), PENNER, M. J., \& FETH, L. L. Signal detection as a function of contralateral sinusoid-to-noise ratio. Journal of the Acoustical Society of America, 1972, 51, 1966-1970.

\section{VISION}

ALPERN, M. (Vision Rsch. Lab., Depts. of Ophthalmol. \& Physiol., Univ. of Michigan, Ann Arbor, Mich. 48104), \& OHBA, N. The effect of bleaching and backgrounds on pupil size. Vision Research, $1972,12,943-951$.

CROWDER, R. G. (Yale Univ., New Haven, Conn. 06510), \& DAVIS, K. $\mathrm{L}$. The relation between lisping and visual recognition memory in children. Perception \& Psychophysics, 1972, 11, 393-397. DIXON, N. F. (Univ. Coll. London, London W.C.1, England), \& HAMMOND, E. J. The attenuation of visual persistence. British Journal of Psychology, 1972, 63, 243-254.

MARTIN, D. W. (New Mexico State Univ., Las Cruces, N. Mex. 88001), \& RICHARDS, E. Locus of selectivity in a visual memory task using a color value indicator. Perception \& Psychophysics, 1972, 12, 65-68.

MERSHON, D. H. (York Univ., Downsview, Ont., Canada). Relative contributions of depth and directional adjacency to simultaneous whiteness contrast. Vision Research, 1972, 12, 969-979.

MEWHORT, D. J. K. (Queen's Univ., Kingston, Ont., Canada), \& CORNETT, S. Scanning and the familiarity effect in tachistoscopic recognition. Canadian Journal of Psychology, 1972, 26, 181-189.

SCHURMAN, D. L. (Emory Univ., Atlanta, Ga. 30322), EVERSON, M D., \& ROLLINS, H. A. Successive vs simultaneous processing of superimposed visual stimuli. Perception \& Psychophysics, 1972, $11,420-422$

SMITH, G. J. W. (Univ. of Lund, Lund 1, Sweden), \& SJOEHOLM, L. Manipulation of projected afterimages by means of the physiological theory imposed on the observer. Perceptual \& Motor Skills, 1972, 34, 975-981.

STANNERS, R. F. (Oklahoma State 
Univ., Stillwater, Okla. 74074), HEADLEY, D. B., \& CLARK, W. R. The pupillary response to sentences: Influences of listening set and deep structure. Journal of Verbal Learning \& Verbal Behavior, 1972, 11, 257-263.

SUNDET, J. M. (Sec. of Sensory Psychol. \& Psychophysiol., Inst. of Psychol., Univ. of Oslo, Oslo, Norway). The effect of pupil size variations on the colour stereoscopic phenomenon. Vision Research, 1972, 12, 1027-1032.

WALLACH, H. (Swarthmore Coll., Swarthmore, Pa. 19081), \& SMITH, A. Visual and proprioceptive adaptation to altered oculomotor adjustments. Perception \& Psychophysics, 1972, 11, 413-416.

WEBER, R. J. (Oklahoma State Univ., Stillwater, Okla. 74074), \& KELLEY, J. Aspects of visual and acoustic imagery. Psychonomic Science, 1972, 27, 121-122.

WEISSTEIN, N. (Loyola Univ., Chicago, Ill. 60626), MONTALVO, F., \& OZOG, G. Differential adaptation to gratings blocked by cubes and gratings blocked by hexagons: $A$ test of the neural symbolic activity hypothesis. Psychonomic Science, 1972, 27, 89-92.


Winnipeg, Man., Canada), \& ZUBEK, J. P. Progressive increase in the CFF of the non-occluded eye during one week of monocular deprivation. Canadian Journal of Psychology, 1972, 26, 42-53.

DeMARCHI, G. W., \& TONG, J. E. (Birkbeck Coll., Univ. of London, London W.C.1, England). Menstrual, diurnal, and activation effects on the resolution of temporally paired flashes. Psychophysiology, 1972, 9, 362-367.

ELLIOTT, R. (Dartmouth Coll., Hanover, N.H. 03755), \& GRAF, V. $V$ isual sensitivity as a function of phase of cardiac cycle. Psychophysiology, 1972, 9, 357-361.

FRIEDMAN, S. (John F. Kennedy Ctr. for Rsch. on Ed. \& Human Dev., George Peabody Coll., Box 512 , Nashville, Tenn. 37203). Habituation and recovery of visual response in the alert human newborn. Journal of Experimental Child Psychology, 1972, 13, 339-349.

FRUMKES, T. E. (Queens Coll. of CUNY, Flushing, N.Y. 11367), SEKULER, M. D., \& REISS, E. H. Rod-cone interaction in human scotopic vision. Science, 1972, 175, 913-914.
OHBA, N. (Vision Rsch. Lab., Depts. of Ophthalmol. \& Physiol., Univ. of Michigan, Ann Arbor, Mich. 48104 ), \& ALPERN, M. Adaptation of the pupil light reflex. Vision Research, 1972, 12, 953-967.

PYKE, S. W. (York Univ., Toronto, Ont., Canada). Novelty, recency and frequency effects on visual recognition and pseudo-recognition thresholds. Perceptual \& Motor Skills, 1972, 34, 847-856.

RUSHTON, W. A. H. (Inst. of Molecular Biophysics, Florida State Univ., Tallahassee, Fla. 32306), \& POWELL, D. S. The early phase of dark adaptation. Vision Research, 1972, 12, 1083-1093.

RUSHTON, W. A. H. (Inst. of Molecular Biophysics, Florida State Univ., Tallahassee, Fla. 32306), \& POWELL, D. S. The rhodopsin content and the visual threshold of human rods. Vision Research, 1972, 12, 1073-1081.

STEVENS, J. C. (John B. Pierce Fdtn. Lab., 290 Congress Ave., New Haven, Conn. 06519), \& MARKS, L. E. Brightness function: Role of the pupil. Perception \& Psychophysics, 1972, 11, 403-405. van MEETEREN, A. (Inst. for Percep. T NO, Soesterberg, The Netherlands), \& VOS, J. J. Resolution and contrast sensitivity at low luminances. Vision Research, $1972,12,825-833$.

WARREN, D. H. (Univ. of California, Riverside, Calif. 92501). Temporal decay of contralateral suppressive fields. Perceptual \& Motor Skills, $1972,34,970$.

WEINGARTEN, F. S. (Learning Resources Lab., City Coll. of Chicago, 5400 N. St. Louis Ave., Chicago, Ill. 60625). Wavelength effect on visual latency. Science, $1972,176,692-694$.

ZUBEK, J. P. (Univ. of Manitoba, Winnipeg, Man., Canada), \& BROSS, M. Depression and later enhancement of the critical flicker frequency during prolonged monocular deprivation. Science, 1972, 176, 1045-1047.

\section{Spatial Vision}

CosGrove, M. P. (Purdue Univ., Lafayette, Ind. 47907), SCHMIDT, M. J., FULGHAM, D. D., \& BROWN, D. R. Stabilized images: Dependent variable specificity of pattern-specific effects with prolonged viewing. Perception \& Psychophysics, 1972, 11, 398-402. CREIGHTON, T. D. (Queen's Univ., Kingston, Ont, Canada), TEES, R. C., \& CREIGHTON, D. E. Occipital EEG activity during fluctuations of perception under stabilized image and simplified stimulus conditions. Canadian Journal of Psychology,
$1972,26,127-139$.

LURIA, S. M. (Nav. Submarine Med. Ctr., Groton, Conn. 06340), \& KINNEY, J. A. S. Peripheral stimuli and stereoacuity under water. Perception \& Psychophysics, 1972, 11, 437-440.

MONTI, P. M. (Univ. of Rhode Island, Kingston, R.I. 02881). Effect of reference points and masking on tachistoscopic pattern perception. Perceptual \& Motor Skills, 1972, 34, 923-940.

OWEN, W. G. (Jules Stein Eye Inst., Sch. of Med., Univ. of California, Los Angeles, Calif. 90024). Spatio-temporal integration in the human peripheral retina. Vision Research, 1972, 12, 1011-1026.

ROSS, H. E. (Univ. of Stirling, Stirling, Scotland), \& REJMAN, M. H. Adaptation to speed distortions under water. British Journal of Psychology, 1972, 63, 257-264.

SCHMIDT, M. J. (Purdue Univ., L a fa yet te, Ind . 47907), COSGROVE, M. P., \& BROWN, D. R. Stabilized images: Functional relationships among populations of orientation-specific mechanisms in the human visual system. Perception $\&$ Psychophysics, 1972, 11, 389-392.

SEKULER, R. (Cresap Lab. of Neurosci. \& Behav., Northwestern Univ., Evanston, Ill. 60201), \& NASH, D. Speed of size scaling in human vision. Psychonomic Science, 1972, 27, 93-94.

SINDERMANN, F. (Dept. of Neurol. $\&$ Sec. of Neurophysiol., Univ. of Ulm, 79 Ulm, Western Germany), \& L Ü D D E K E, H. Monocular analogues to binocular contour rivalry. Vision Research, 1972, 12, 763-772.

TOLHURST, D. J. (Physiol. Lab., Univ. of Cambridge, Cambridge, CB2 3EG, England). On the possible existence of edge detector neurones in the human visual system. Vision Research, 1972, 12, 797-804.

\section{Form Perception}

BIEDERMAN, I. (State Univ. of New York, Buffalo, N.Y. 14226). Perceiving real-world scenes. Science, 1972, 177, 77-80.

GREENBERG, J. W. (City Coll., CUNY, New York, N.Y. 10010). Synthesis and analysis of visually perceived forms by young children. Perceptual \& Motor Skills, 1972, 34, 735-741.

MANDLEBERG, I. A. (Behav. Sci. Dept., Inst. of Rehabilitation Med., New York Univ. Med. Ctr., New York, N.Y. 10016). Visual matching as a function of stimulus complexity in normal and brain-injured persons. Perceptual \& Motor Skills, 1972, 34, 859-866. 
McDONNELL, P. M. (Univ. of New Brunswick, Fredericton, N.B. Canada), \& DUFFETT, J. Vision and touch: $A$ reconsideration of conflict between the two senses. Canadian Journal of Psychology, 1972, 26, 171-180.

\section{Depth Perception}

COREN, S. $(66$ W. 12th St., New York, N.Y. 10011). Subjective contours and apparent depth. Psychological Review, 1972, 79, 359-367.

FOLEY, J. M. (Univ, of California, Santa Barbara, Calif. 93106), \& RICHARDS, W. Effects of voluntary eye movement and convergence on the binocular appreciation of depth. Perception \& Psychophysics, 1972, 11, 423-427.

HOLT-HANSEN, K. (Psychol. Lab., Copenhagen Univ., DK 1166 , Co pen hagen, Denmark). Experienced attraction between two parallel bars. Perceptual \& Motor Skills, 1972, 34, 971-974.

LAWSON, E. A. (Sch. of Studies in Psychol., Univ. of Bradford, Richmond Rd., Bradford, Yorkshire, England BD7 1DP) Vertical disparities. British Journal of Psychology, 1972, 63, 265-270.

ROGERS, B. J. 18-10 Berkeley Square, Bristol, BS8 $1 \mathrm{HH}$, England), \& ANSTIS, $S$. M. Intensity versus adaptation and the Pulfrich stereophenomenon. Vision Research, 1972, 12, 909-928.

SMITH, O. W. (Bowling Green State Univ., Bowling Green, Ohio 43403), SMITH, P. C., \& KOUTSTAAL, C. W. Apparent parallelism: Uni- or multidimensional? Perceptual \& Motor Skills, 1972, 34, 834.

\section{Masking}

BARRY, S. H. (Ctr. for Vis. Sci., Univ. of Rochester, Rochester, N.Y. 14627), \& DICK, A. O. On the "recovery" of masked targets. Perception \& Psychophysics, 1972, 12, 117-120.

BECK, J. (Univ. of Oregon, Eugene, Oreg. 97403), \& AMBLER, B. Discriminability of differences in line slope and in line arrangement as a function of mask delay. Perception \& Psychophysics, 1972, $12,33-38$

DEMBER, W. N. (Univ. of Cincinnati, Cincinnati, Ohio 45221), COLINA, T. L., \& SHERRICK, M. F. Amount vs contrast of masking-figure contour in visual backward masking. Psychonomic Science, 1972, 27, 95-96.

ERIKSEN, C. W. (Univ. of Illinois, Champaign, Ill. 61820), \& ERIKSEN, B. A. Visual backward masking as measured by voice reaction time. Perception \&
Psychophysics, 1972, 12, 5-8.

GALBRAITH, G. C. (Pacific State Hosp., Pomona, Calif. 91766), \& GLIDDON, J. B. Backward visual masking with homogeneous and patterned stimuli: Comparison of retarded and nonretarded subjects. Perceptual \& Motor Skills, 1972, 34, 903-908.

MONTI, P. M. (Univ. of Rhode Island, Kingston, R.I. 02881). Effect of reference points and masking on tachistoscopic pattern perception. Perceptual \& Motor Skills, 1972 , $34,923-940$.

RICHARDS, W. (M.I.T., Cambridge Mass. 02139). Disparity masking. Vision Research, 1972, 12, 1113-1124.

SCHARF, B. (Northeastern Univ. Boston, Mass. 02115), \& FULD, K. Reduction of visual masking by a priming flash. Journal of Experimental Psychology, 1972, 94, 116-118.

TAYLOR, S. G. (Purdue Univ., Lafayette, Ind. 47907), \& BROWN, D. R. Lateral visual masking: Supraretinal effects when viewing linear arrays with unlimited viewing time. Perception \& Psychophysics, $1972,12,97-99$.

WEISSTEIN, N. (Loyola Univ., Chicago, Ill. 60626), \& BISAHA, J. Gratings mask bars and bars mask gratings: Visual frequency response to aperiodic stimuli. Science, 1972, $176,1047-1049$

\section{Eye Movements}

ARKIN, A. M. (City Coll. of CUNY, New York, N.Y. 10031), LUTZKY, H., \& TOTH, M. F. Congenital nystagmus and sleep: A replication. Psychophysiology, 1972, 9, 210-217.

BERGER, R. J. (Div. of Natural Sci., Univ. of California, Santa Cruz, Calif. 95060), \& WALKER, J. M. Oculomotor coordination following REM and non-REM sleep periods. Journal of Experimental Psychology, 1972, 94, 216-224.

BICAS, H. E. A. (Departamento de Oftalmologia, Faculdade de Medicina de Ribeirão Prèto da Universidade de São Paulo, Ribeirão P r e t o-S P - B r a z i l). Electro-oculography in the investigation of oculomotor imbalance-I. Basic aspects. Vision Research, 1972, 12, 993-1010.

CARPENTER, P. A. (Carnegie-Mellon Univ., Pittsburgh, Pa. 15213), \& JUST, M. A. Semantic control of eye movements in picture scanning during sentence-picture verification. Perception \& Psychophysics, 1972 , $12,61-64$

FOLEY, J. M. (Univ. of California, Santa Barbara, Calif. 93106), \& RICHARDS, W. Effects of voluntary eye movement and convergence on the binocular appreciation of depth. Perception \& Psychophysics, 1972, 11, 423-427. HEYWOOD, S. (Bionies Rsch. Lab., Sch. of Artificial Intelligence, Univ. of Edinburgh, Forrest Hill, Edinburgh 8, Scotland), \& CHURCHER, J. Eye movements and the after-image-II. The effect of foveal and non-foveal after-images on saccadic behaviour. Vision Research, 1972, 12, 1033-1043.

KOCEL, K. (Langley Porter Neuropsychiat. Inst., San Francisco, Calif. 94122), GALIN, D., ORNSTEIN, R., \& MERRIN, E. L. Lateral eye movement and cognitive mode. Psychonomic Science, 1972, 27, 223-224.

\section{AUDITION}

CHOVAN, W. L. (Western Carolina Univ., Cullowhee, N.C. 28723). Conceptual organization of recall in an object arrangement task with deaf and hearing children. Perceptual \& Motor Skills, 1972, 34,742 .

DEUTSCH, D. (Ctr. for Human Information Processing, Univ. of California, San Diego, La Jolla, Calif. 92037). Octave generalization and tune recognition. Perception \& Psychophysics, 1972, 11, 411-412. FUREDY, J. J. (Univ. of Toronto, Toronto 181, Ont., Canada), FAINST A T, D., KULIN, P., LASKO, L., \& NICHOLS, S. Preparatory-response vs information-seeking interpretations of preference for signaled loud noise: Further limits on human informational cognitive control. Psychonomic Science, 1972, 27, 108-110.

GEN G E L, R. W. (Sensory Communication Rsch. Lab., Hearing \& Speech Ctr., Gallaudet Coll., Washington, D.C. 20002). Auditory temporal integration at relatively high masked-threshold levels. Journal of the Acoustical Society of America, 1972, 51, 1849-1851.

HAFTER, E. R. (Univ. of California, Berkeley, Calif. 94720), \& C ARRIER, S. C. Binaural interaction in low-frequency stimuli: The inability to trade time and intensity completely. Journal of the Acoustical Society of America, 1972, 51, 1852-1862.

HALL, J. L. (Bell Labs., Murray Hill, N.J. 07974). Auditory distortion products $f_{2}-f_{1}$ and $2 f_{1}-f_{2}$. Journal of the Acoustical Society of America, 1972, 51, 1863-1871.

HALL, J. L. (Bell Labs., Murray Hill, N.J. 07974). Monaural phase effect: cancellation and reinforcement of distortion products $f_{2}-f_{1}$ and 
$2 f_{1}-f_{2}$. Journal of the Acoustial Society of America, 1972, 51, 1872-1881.

HAMERS, J. F. (McGill Univ., Montreal 110, P.Q., Canada), \& LAMBERT, W. E. Bilingual interdependencies in auditory perception. Journal of Verbal Learning \& Verbal Behavior, 1972, $11,303-310$.

HOLMES, V. M. (M.I.T., Cambridge, Mass. 02139), \& FORSTER, K. I. Click location and syntactic structure. Perception \& Psychophysics, 1972, 12, 9-15.

HOUTGAST, T. (Inst. for Percep. RVO-TNO, Soesterberg, The Netherlands). Psychophysical evidence for lateral inhibition in hearing. Journal of the Acoustical Society of America, 1972, 51 , 1885-1894.

HUBBARD, A. E. (Electrical Eng. Dept., Univ. of Wisconsin, Madison, Wis. 53706), \& GEISLER, C. D. A hybrid-computer model of the cochlear partition. Journal of the Acoustical Society of America, 1972, 51, 1895-1903.

KING, F. L. (Univ. of Western Ontario, London, Ont., Canada), \& KIMURA, D. Left-ear superiority in dichotic perception of vocal nonverbal sounds. Canadian Journal of Psychology, 1972, 26, 111-116.

LESHOWITZ, B. (Arizona State Univ., Tempe, Ariz. 85281), \& CUDAHY, E. Masking with continuous and gated sinusoids. Journal of the Acoustical Society of America, 1972, 51, 1921-1929.

LUMMIS, R. C. (Bell Labs., Murray Hill, N.J. 07974), \& GUTTMAN, N. Exploratory studies of Zwicker's "negative afterimage" in hearing. Journal of the Acoustical Society of America, 1972, 51, 1930-1944.

MASSARO, D. W. (Univ. of Wisconsin, Madison, Wis. 53706). Stimulus information vs processing time in auditory pattern recognition. Perception \& Psychophysics, 1972, $12,50-56$.

SCOTT, T. D. (Univ. of California, Santa Cruz, Calif. 95060). The effects of continuous, high intensity, white noise on the human sleep cycle. Psychophysiology, 1972, 9, 227-232.

WARREN, R. M. (Univ. of Wisconsin, Milwaukee, Wis. 53201 ), \& OBUSEK, C. J. Identification of temporal order within auditory sequences. Perception \& Psychophysics, 1972, 12, 86-90.

WARREN, R. M. (Univ. of Wisconsin, Milwaukee, Wis. 53201), OBUSEK, C. J., \& ACKROFF, J. M. Auditory induction: Perceptual synthesis of absent sounds. Science, 1972,176 , 1149-1151.

WEBER, R. J. (Oklahoma State Univ.,
Stillwater, Okla. 74074), \& KELLEY, J. Aspects of visual and acoustic imagery. Psychonomic Science, 1972, 27, 121-122.

\section{Auditory Discrimination}

CARVELLAS, T. (Columbia Univ., New York, N.Y. 10027), \& SCHNEIDER, B. Direct estimation of multidimensional tonal dissimilarity. Journal of the Acoustical Society of America, $1972,51,1839-1848$.

DOEHRING, D. G. (McGill Univ., Montreal, P.Q., Canada). Ear asymmetry in the discrimination of monaural tonal sequences. Canadian Journal of Psychology, 1972, 26, 106-110.

HALL, J. L. (Bell Labs., Murray Hill, N.J. 07974), \& SCHROEDER, M. R. Monaural phase effects for two-tone signals. Journal of the Acoustical Society of America, 1972, 51, 1882-1884.

ROBINSON, D. E. (Indiana Univ., Bloomington, Ind. 47401), \& DOLAN, T. R. Effect of signal frequency on the MLD for uncorrelated noise. Journal of the Acoustical Society of America, $1972,51,1945-1946$.

SCHNEIDER, B. (Columbia Univ., New York, N.Y. 10027), WRIGHT, A. A., EDELHEIT, W., HOCK, P., \& HUMPHREY, C. Equal loudness contours derived from sensory magnitude judgments. Journal of the Acoustical Society of America, 1972, 51, 1951-1959.

SUEN, C. Y. (Dept. of Electrical Eng., Univ. of British Columbia, Vancouver 8, B.C., Canada), \& BEDDOES, M. P. Discrimination of vowel sounds of very short duration. Perception \& Psychophysics, 1972, 11, 417-419.

\section{Speech Discrimination}

BEASLEY, D. S. (Michigan State Univ., East Lansing, Mich. 48823), ZEMLIN, W. R., \& SILVERMAN, F. H. Listeners' judgments of sex, intelligibility, and preference for frequency-shifted speech. Perceptual \& Motor Skills, 1972, 34, 782 .

BLUMSTEIN, S. (Brown Univ., Providence, R.I. 02912), \& COOPER, $W$. Identification versus discrimination of distinctive features in speech perception. Quarterly Journal of Experimental Psychology, 1972, 24, 207-214.

CHAPIN, P. G. (Univ. of California, San Diego, La Jolla, Calif. 92037), SMITH, T. S., \& ABRAH AMSON, A. A. Two factors in perceptual segmentation of speech. Journal of Verbal Learning \& Verbal Behavior, $1972,11,164-173$.
COLE, R. A. (Univ. of Waterloo, Waterloo, Ont., Canada), \& SCOTT, B. Distinctive feature control of decision time: Same-different judgments of simultaneously heard phonemes. Perception \& Psychophysics, 1972, 12, 91-94.

CONRAD, R. (Nuffield Hearing \& Speech Ctr., 330 Grays Inn Rd., Lond on W.C.1, England). Short-term memory in the deaf: A test for speech coding. British Journal of Psychology, 1972, 63, 173-180.

FLANAGAN, J. L. (Bell Tel. Labs., Murray Hill, N.J. 07974). Voices of men and machines. Journal of the Acoustical Society of America, 1972, 51, 1375-1387.

LEHISTE, I. (Dept. of Linguistics, Ohio State Univ., Columbus, Ohio 43210). The timing of utterances and linguistic boundaries. Journal of the Acoustical Society of America, 1972, 51, 2018-2024.

MATTINGLY, I. G. (Haskins Labs., 270 Crown St., New Haven, Conn. 06511). An ethological view of speech perception and the origin of language. American Scientist, 1972, $60,327-337$.

SCHWARTZ, M. F. (Speech Rsch. Lab., Temple Univ., Coll. of Liberal Arts, Philadelphia, Pa. 19122). Bilabial closure durations for $/ \mathbf{p} /$, $/ \mathrm{b} /$, and $/ \mathrm{m} /$ in voiced and whispered vowel environments. Journal of the Acoustical Society of America, 1972, 51, 2025-2029.

TOSI, O. (Michigan State Univ., East Lansing, Mich. 48823), OYER, H., LASHBROOK, W., PEDREY, C. NICOL, J., \& NASH, E. Experiment on voice identification. Journal of the Acoustical Society of America, 1972, 51, 2030-2043.

WEIST, R. M. (Univ. of Nebraska, Lincoln, Nebr. 68508), \& STEBBINS, $P$. Adult perception of children's speech. Psychonomic Science, 1972, 27, 359-360.

WOLF, J. J. (Bolt Beranek \& Newman, Inc., Cambridge, Mass. 02138). Efficient acoustic parameters for speaker recognition. Journal of the Acoustical Society of America, 1972, 51, 2044-2056.

\section{LOWER SENSES}

FERRIS, S. H. (Nav. Submarine Med. Ctr., Groton, Conn. 06340). Loss of position constancy underwater. Psychonomic Science, 1972, 27, 337-338.

JONES, B. (Univ. of Queensland, St. Lucia, Queensland, Australia 4067). Outflow and inflow in movement duplication. Perception \& Psychophysics, 1972, 12, 95-96. ROVEE, C. K. (Rutgers-The State Univ., Douglass Coll., New Brunswick, N.J. 08903). Olfactory 
cross-adaptation and facilitation in human neonates. Journal of Experimental Child Psychology, 1972, 13, 368-381.

\section{Skin Senses}

CARLSON, K. R. (Dept. of Pharmacol., Univ. of Pittsburgh Sch. of Med., Pittsburgh, Pa. 15213), \& SPALLA, L. J. A system for cutaneous electrical stimulation mimicking touch. Behavior Research Methods \& Instrumentation, 1972, 4, 199-200.

CHYATTE, C. (DePaul Univ., Chicago, Ill. 60614), CHYATTE, D., \& CHYATTE, C. Pain sensitivity reduced through mild cutaneous electrostimulation. Studia Psychologica, 1972, XIV, 180-182.

GAUSSIN, J. (Centre de Psychologie Expérimentale et Comparée, B-3041, Pellenberg, Belgium), \& HUPET, B. An experimental validation of the signal detection theory for active touch. Psychonomic Science, 1972, 27, 339-341.

HALL, D. E. (Elmhurst Coll., Elmhurst, Ill. 60126), FUCCI, D. J., \& ARNST, D. J. Vibrotactile stimulation: An investigation of psychophysical methods for establishing threshold. Perceptual \& Motor Skills, 1972, 34, 891-898.

McDONNELL, P. M. (Univ. of New Brunswick, Fredericton, N.B., Canada), \& DUFFETT, J. Vision and touch: A reconsideration of conflict between the two senses. Canadian Journal of Psychology, 1972, 26, 171-180.

TURSKY, B. (Dept. of Political Sci., State Univ. of New York, Stony Brook, N.Y. 11790$), \quad$ \& O'CONNELL, D. Reliability and interjudgment predictability of subjective judgments of electrocutaneous stimulation. Psychophysiology, 1972, 9, 290-295.

\section{Proprioception}

BAILY, J. S. (Lab. of Exptl. Psychol., Univ. of Sussex, Falmer, Brighton, England). Arm-body adaptation with passive arm movements. Perception \& Psychophysics, 1972, $12,39-44$.

WALLACH, H. (Swarthmore Coll., Swarthmore, Pa. 19081), \& SMITH, A. Visual and proprioceptive adaptation to altered oculomotor adjustments. Perception \& Psychophysics, 1972, 11, 413-416.

WEISSMAN, S. (Lafayette Coll., Easton, Pa. 18042), \& DZENDOLET, E. Effects of visual cues on the standing body sway of males and females. Perceptual \& Motor Skills, 1972, 34, 951-959.

\section{PERFORMANCE}

GLASS, D. C. (Univ. of Texas, Austin, Tex. 78712) \& SINGER, J. E. Behavioral aftereffects of unpredictable and uncontrollable aversive events. American Scientist, $1972,60,457-465$.

GROEN, G. J. (Carnegie-Mellon Univ., Pittsburgh, Pa. 15213), \& PARKMAN, J. M. A chronometric analysis of simple addition. Psychological Review, 1972, 79, 329-343.

HICKS, J. A., III. (North Carolina State Univ., Raleigh, N.C. 27607). Error detection performance in a proportion estimation task. Psychonomic Science, 1972, 27, 105-107.

KANEKAR, S., \& ROSENBAUM, M. E. (Univ. of Iowa, Iowa City, Iowa 52240). Group performance on a multiple-solution task as a function of available time. Psychonomic Science, 1972, 27, 331-332.

LUCZAK, H. (Institut für Arbeitswissenschaft, Univ. of Tech., Darmstadt, German Federal Republic). The use of simulators for testing individual mental working capacity. Ergonomics, 1971, 14, 651-660.

MUNNS, M. (Crew Systems Dept., Nav. Air Dev. Ctr., Warminster, Pa. 18974). Recent research applicable to the design of electronic displays. Perceptual \& Motor Skills, 1972, 34, 683-690.

RUGH, J. D. (Univ. of California, Santa Barbara, Calif. 93106). Variation in human masticatory behavior under temporal constaints. Journal of Comparative \& Physiological Psychology, 1972, 80, 169-174.

\section{PSYCHOMOTOR TASKS}

BAIRD, J. C. (Dartmouth Coll., Hanover, N.H. 03755 ), \& DEGERMAN, $R$. People planning by a fixed resource method. Perceptual \& Motor Skills, 1972, 34, 799-806.

BROADHEAD, G. D. (Dept. of Special Ed., Moray House Coll. of Ed., Edinburgh, Scotland). Gross motor performance in minimally brain injured children. Journal of Motor Behavior, 1972, 4, 103-111. BURWITZ, L. (Children's Rsch. Ctr., Univ. of Illinois, Champaign, Ill. 61820), \& NEWELL, K. M. The effects of the mere presence of coactors on learning a motor skill. Journal of Motor Behavior, 1972, 4, 99-102.

FUREDY, J. J. (Univ. of Toronto, Toronto 181, Ont., Canada), FAINSTAT, D., KULIN, P.,
LASKO, L., \& NICHOLS, S. Preparatory-response vs information-seeking interpretations of preference for signaled loud noise: Further limits on human informational cognitive control. Psychonomic Science, 1972, 27, 108-110.

GARVIE, G. T. (Dept. of Physical Ed. Lakehead Univ., Port Arthur, Ont., Canada). Stress and motor performance and learning by Ss of low and high initial ability. Perceptual \& Motor Skills, 1972, 34, 819-824.

GERBEN, M. J., HOUSE, J. L. (U.S. Army Rsch. Inst. of Environmental Med., Natick, Mass. 01760), \& WINSMANN, F. R. Self-paced ergometer performance: Effects of pedal resistance, motivational contingency and inspired oxygen concentration. Perceptual \& Motor Skills, 1972, 34, 875-881.

JEEVES, M. A. (Univ. of St. Andrews, St. Andrews, Fife, Scotland). Hemisphere differences in response rates to visual stimuli in children. Psychonomic Science, 1972, 27, 201-203.

LASZLO, J. I. (Univ. of Western Australia, Nedlands, Western Australia), \& BAKER, J. E. The role of visual cues in movement control and motor memory. Journal of Motor Behavior, 1972, 4, 71-78.

MURAM, D., \& CARMON, A. (Lab. of Human Psychophysiol., Dept. of Neurol., Hadassah Univ. Hosp., POB 499, Jerusalem, Israel). Behavioral properties of som a tose n s or y-motor interhemispheric transfer. Journal of Experimental Psychology, 1972, 94, 225-230.

NICKI, R. M. (Univ. of New Brunswick, Fredericton, N.B., Canada). Arousal increment and degree of complexity as incentive. British Journal of Psychology, $1972,63,165-171$.

RIVENES, R. S. (California State Coll., Hayward, Calif. 94541), \& CAPLAN, C. S. Concurrent task practice conditions and transfer. Perceptual \& Motor Skills, 1972, 34, 941-942.

ROTHSTEIN, A. L. (Dept. of Physical Ed., Herbert $H$. Lehman Coll., Bronx, N.Y. 10468). Effect of age, feedback, and practice on ability to respond within a fixed time interval. Journal of Motor Behavior, 1972, 4, 113-120.

SCHMIDT, R. A. (Dept. of Physical Ed., Univ. of Michigan, Ann Arbor, Mich. 48104). The case against learning and forgetting scores. 
Journal of Motor Behavior, 1972, 4, 79-88.

SCHMIDT, R. A. (Dept. of Physical Ed., Univ. of Michigan, Ann Arbor, Mich. 48104). The index of preprogramming (IP): A statistical method for evaluating the role of feedback in simple movements. Psychonomic Science, 1972, 27, 83-85.

SPERANDIO, J. C. (Institut de Recherche d'Informatique et d'Automatique, Domaine de Voluceau, 78-Rocquencourt, France). Variation of operator's strategies and regulating effects on workload. Ergonomics, 1971, 14, 571-577.

STIMBERT, V. E. (Univ. of Tennessee Child Dev. Ctr., Memphis, Tenn. 38105). Response latencies in delayed matching-to-sample as function of delay interval and social condition. Psychonomic Science, 1972, 27, 211-213.

WHITING, H. T. A. (Dept. of Physical Ed., Univ. of Leeds, Leeds, England), \& HUTT, J. W. R. The effects of personality and ability on speed of decisions regarding the directional aspects of ball flight. Journal of Motor Behavior, 1972, 4, 89-98.

WILLIAMS, I. D. (Dept. of Kinesiol., Univ. of Waterloo, Waterloo, Ont., Canada), \& ROY, E. A. Closed-loop control of a ballistic response. Journal of Motor Behavior, 1972, 4, 121-126.

\section{Reaction Time}

COOTS, J. H. (Univ. of Utah, Salt Lake City, Utah 84112), \& JOHNSTON, W. A. The effects of speed and accuracy strategies in an information-reduction task. Perception \& Psychophysics, 1972, 12, 1-4.

FALMAGNE, J. C. (New York Univ., New York, N.Y. 10003). Biscalability of error matrices and all-or-none reaction time theories. Journal of $\mathrm{M}$ athematical Psychology, 1972, 9, 206-224.

GREEN, T. R. G. (MRC Unit for Soc. \& Applied Psychol., Univ. of Sheffield, Sheffield, England), SIME, M. E., \& GUEST, D. J. Some types of error in a choice response task. Quarterly Journal of Experimental Psychology, 1972, 24, 149-158.

GRICE, G. R. (Univ. of New Mexico, Albuquerque, N. Mex. 87106). Application of a variable criterion model to auditory reaction time as a function of the type of catch trial. Perception \& Psychophysics, 1972, 12, 103-107.

GUEST, D. J. (MRC Soc. \& Applied Psychol. Unit, Univ. of Sheffield, Sheffield, England), SIME, M. E., \&
GREEN, T. R. G. Error patterns in a chord keyboard response task. Quarterly Journal of Experimental Psychology, 1972, 24, 139-148.

HOLLOWAY, F. A. (Whiteman House for Mental Rsch., 607 N.E. 15th St., Oklahoma City, Okla. 73104), \& PARSONS, O. A. Physiological concomitants of reaction time performance in normal and brain-damaged subjects. Psychophysiology, 1972, 9, 189-198.

LOVELACE, E. A. (Univ. of Virginia, Charlottesville, Va. 22901), \& SPENCE, W. A. Reaction times for naming successive letters of the alphabet. Journal of Experimental Psychology, 1972, 94, 231-233.

MOSCOVITCH, M. (Erindale Coll., Univ. of Toronto, Clarkson, Ont., Canada). Choice reaction-time study assessing the verbal behavior of the minor hemisphere in normal adult humans. Journal of Comparative \& Physiological Psychology, 1972, 80, 66-74.

REBERT, C. S. (Neurophysiol. Lab., Life Sci. Rsch., Stanford Rsch. Inst., Menlo Park. Calif. 94025). The effect of reaction time feedback on reaction time and contingent negative variation. Psychophysiology, 1972, 9, 334-339.

STEVENS, J. R. (Dept. of Psychiat., Massachusetts Gen. Hosp., Boston, Mass. 02114), LONSBURY, B., \& GOEL, S. Electroencephalographic spectra and reaction time in disorders of higher nervous function. Science, 1972, 176, 1346-1349.

STILITZ, I. (Hebrew Univ, of Jerusalem, Jerusalem, Israel). Conditional probability and components of $\mathrm{RT}$ in the variable foreperiod experiment. Quarterly Journal of Experimental Psychology, 1972, 24, 159-168.

TEICHNER, W. H. (New Mexico State Univ., Box 3452, Las Cruces, N. Mex. 88001), \& KREBS, M. J. Laws of the simple visual reaction time. Psychological Review, 1972, 79, 344-358.

WATTENBARGER, B. L. (Bell Tel. Labs., Holmdel, N.J. 07733), \& PACHELLA, R. G. The effect of memory load on reaction time in character classification. Perception \& Psychophysics, 1972, 12, 100-102.

\section{Stroop}

BONE, R. N. (West Virginia Wesleyan Coll., Buckhannon, W. Va. 26201), \& EYSENCK, H. J. Extraversion, field-dependence, and the Stroop test. Perceptual \& Motor Skills, $1972,34,873-874$.

DALRYMPLE-ALFORD, E. C. (Trent
Univ., Peterborough, Ont., Canada), \& AZKOUL, J. The locus of interference in the Stroop and related tasks. Perception \& Psychophysics, 1972, 11, 385-388. SHOR, R. E. (Univ. of New Hampshire, Durham, N.H. 03824), HATCH, R. P., HUDSON, L. J., LANDRIGAN, D. T., \& SHÁFFER, H. J. Effect of practice on a Stroop-like spatial directions task. Journal of Experimental Psychology, 1972, 94, 168-172.

\section{ATTENTION}

ALLPORT, D. A. (Reading Univ., Reading, England), ANTONIS, B., \& REYNOLDS, $P$. On the division of attention: A disproof of the single channel hypothesis. Quarterly Journal of Experimental Psychology, 1972, 24, 225-235.

BERNICK, N. (NIMH Clinical Rsch. Ctr., P.O. Box 2000, Lexington, Ky. 40507). Relationship between age and pupil size: Some additional variables. Perceptual \& Motor Skills, 1972, 34, 727-731.

BROWN, A. L. (Children's Rsch. Ctr., Univ. of Illinois, Champaign, Ill. 61820 ), \& SCOTT, K. G. Psychophysically scaled cue differences, learning rate, and attentional strategies in a tactile discrimination task. Journal of Experimental Child Psychology, 1972, 13, 283-302.

CARPENTER, P. A. (Carnegie-Mellon Univ., Pittsburgh, Pa. 15213), \& GANZ, L. An attentional mechanism in the analysis of spatial frequency. Perception \& Psychophysics, 1972, 12, 57-60.

EPSTEIN, W. (Univ. of Wisconsin, Madison, Wis. 53706), MASSARO, D. W., \& WILDER, L. Selective search in directed forgetting. Journal of Experimental Psychology, 1972, 94, 18-24.

GREENWALD, A. G. (Ohio State Univ., Columbus, Ohio 43210). Evidence of both perceptual filtering and response suppression for rejected messages in selective attention. Journal of Experimental Psychology, 1972, 94, 5867.

NELSON, T. M. (Úniv. of Alberta, Edmonton 7, Alta., Canada), SMMS, J., \& ALLAN, D. An experimental study of the selective attention of children of 1896 and 1966 . Journal of Genetic Psychology, 1972, 120, 317-324.

SHEPP, B. E. (Brown Univ., Providence, R.I. 02912), KEMLER, D. G., \& ANDERSON, D. R. Selective attention and the breadth of learning: An extension of the one-look model. Psychological Review, 1972, 79, 317-328.

SIDDLE, D. A. T. (Univ. of Southampton, Southampton, 
England). Vigilance decrement and speed of habituation of the GSR component of the orienting response. British Journal of Psychology, 1972, 63, 191-194.

SPENCE, D. P. (Rsch. Ctr. for Mental Health, New York Univ., New York, N.Y. 10003), LUGO, M., \& YOUDIN, R. Cardiac change as a function of attention to and awareness of continuous verbal text. Science, 1972, 176, 1344-1346.

\section{Orienting Response}

BOWER, A. C. (Ctr. for the Study of Mental Retardation, Univ. of Alberta, Edmonton, Alta., Canada), \& DAS, J. P. Acquisition and reversal of orienting responses to word signals. British Journal of Psychology, 1972, 63, 195-203.

COHEN, N. J., \& DOUGLAS, V. I. (McGill Univ., Montreal 101, P.Q., Canada). Characteristics of the orienting response in hyperactive a n d normal children. Psychophysiology, 1972,9 , 238-245.

FREEMAN, B. L. (Memphis State Univ., Memphis, Tenn. 38152), JOHNSON, J. T., JR., \& LONG, C. L. Semantic generalization of the orienting response. Journal of Experimental Research in Personality, 1972, 6, 39-43.

YAREMKO, R. M. (San Diego State Coll., San Diego, Calif. 92115), GLANVILLE, B. B., \& LECKART, B. T. Imagery-mediated habituation of the orienting reflex. Psychonomic Science, 1972, 27, 204-206

YAREMKO, R. M. (San Diego State Coll., San Diego, Calif. 92115), \& KELEMAN, $K$. The orienting reflex and amount and direction of conceptual novelty. Psychonomic Science, 1972, 27, 195-196.

\section{INFORMATION PROCESSING}

ALUMBAUGH, R. V. (Central Washington State Coll., Ellensburg, Wash. 98926), \& TAKEMURA, K. Variable noise and information transmission. Psychonomic Science, 1972, 27, 351-352.

BERNSTEIN, I. H. (Univ. of Texas, Arlington, Tex. 76010 ), PEDERSON, N. N., \& SCHURMAN, D. L. Intersensory versus intrasensory contingent information processing. Journal of Experimental Psychology, 1972, 94, 156-161.

CONNOR, J. M. (Vanderbilt Univ., Nashville, Tenn. 37203). Effects of increased processing load on parallel processing of visual displays. Perception \& Psychophysics, 1972, $12,121-128$

DANEV, S. G. (Netherlands Inst. for Preventive Med. TNO, Leiden, The
Netherlands), de Winter, C. R., \& WARTNA, G. F. Information processing and psychophysiological functions in a task with and without time stress. Activitas Nervosa Superior, 1972, 14, 8-12.

EGETH, H. (Johns Hopkins Univ., Baltimore, Md. 21218), MARCUS, N., \& BEVAN, W. Target-set and response-set interaction: Implications for models of human information processing. Science, $1972,176,1447-1448$

HERZOG, T. R. (Grand Valley State Coll., College Landing, Allendale, Mich. 49401). Effects of presentation rate and prior knowledge of target identity in the repeated-presentations paradigm. Psychonomic Science, 1972, 27, 86-88.

HOLDEN, E. A., JR. (E. R. Johnstone Training \& Rsch. Ctr., Bordentown, N.J. 08505). Effects of modality categorization on unimodal and intermodal sequential information processing in normals and retardates. Psychonomic Science, 1972, 27, 236-238.

McKEEVER, W. F. (Bowling Green State Univ., Bowling Green, Ohio 43403), \& GILL, K. M. Visual half-field differences in the recognition of bilaterally presented single letters and vertically spelled words. Perceptual \& Motor Skills, $1972,34,815-818$.

NORTON, J. C. (Neuropsychol. Lab., Dept. of Neurol., Univ. of Wisconsin Sch. of Med., Madison, Wis. 53706). Effect of set size, age, and mode of stimulus presentation on information-processing speed. Perceptual \& Motor Skills, 1972, 34, 1003-1010.

STAGER, P. (York Univ., Downsview, Ont., Canada), \& ZUFELT, $\mathbf{K}$. Dual-task method in determining load differences. Journal of Experimental Psychology, 1972, 94, 113-115.

WALLSTEN, T. S. (L. L. Thurstone Psychometric Lab., Univ. of North Carolina, Chapel Hill, N.C. 27514). Conjoint-measurement framework for the study of probabilistic information processing. Psychological Review, 1972, 79, 245-260.

\section{SLEEP \& FATIGUE}

ARKIN, A. M. (City Coll. of CUNY, New York, N.Y. 10031), LUTZKY, H., \& TOTH, M. F. Congenital nystagmus and sleep: A replication. Psychophysiology, 1972,9 , 210-217.

BERGER, R. J. (Div. of Natural Sci., Univ. of California, Santa Cruz, Calif. 95060), \& WALKER, J. M. Oculomotor coordination following REM and non-REM sleep periods.
Journal of Experimental Psychology, 1972, 94, 216-224.

GERING, R. C. (Miami Univ., Oxford, Ohio 45056), \& MAHRER, A. R. Difficulty falling asleep. Psychological Reports, 1972, 30, 523-528.

GIAQUINTO, S. (Laboratorio di Cibernetica del C.N.R., 80072 Arco Felice, Italy), \& VENTRIGLIA, F. Analysis of the antigravitary tonic activity in the sleep-wakefulness cycle. Archives Italiennes de Biologie, 1972, Tome 110, 52-69.

GRIFFITHS, W. J. (Dept. of Psychiat., Univ. of Oklahoma Med. Ctr., Oklahoma City, Okla. 73104), LESTER, B. K., COULTER, J. D., \& WILLIAMS, H. L. Tryptophan and sleep in young adults. Psychophysiology, 1972,9 , 345-356.

HUNDAL, P. S. (Punjab Univ., Chandigarh, India), \& GILL, S. A comparative study of the effects of electrical and psychological stimulation on muscular fatigue. Psychophysiology, 1972,9 , 368-372.

JELÍNKOVÁ, Z. (Czechoslovak Acad. of Sci., Prague, Czechoslovakia). Conditioning and differentiation during sleep. Studia Psychologica, 1972, XIV, 109-114.

SCOTT, T. D. (Univ. of California, Santa Cruz, Calif. 95060). The effects of continuous, high intensity, white noise on the human sleep cycle. Psychophysiology, 1972, 9, 227-232.

TIMMONS, B. (Langley Porter Neuropsychiat. Inst., San Francisco, Calif. 94122), SALAMY, J., KAMIYA, J., \& GIRTON, D. Abdominal-thoracic respiratory movements and levels of arousal. Psychonomic Science, 1972, 27, $173-175$

YEN, S. (Essex Community Coll., Essex, Md. 21221), McINTIRE, R. W., \& BERKOWITZ, S. Extinction of inappropriate sleeping behavior: Multiple assessment. Psychological Reports, 1972, 30, 375-378.

\section{PREFERENCE}

FAVELL, JUDITH E. (Western Carolina Ctr., Morganton, N.C. 28655), \& FAVELL, JAMES E. Control of preference in children by conditioned positive reinforcement. Journal of the Experimental Analysis of Behavior, 1972, 18, 107-112.

FISHBURN, P. C. (Inst. for Advanced Study, Princeton, N.Y. 08540). Interdependent preferences on finite sets. Journal of Mathematical Psychology, 1972, 9, 225-236.

SMILEY, S. S. (Western Washington State Coll., Bellingham, Wash. 
98225). Instability of dimensional preference following changes in relative cue similarity. Journal of Experimental Child Psychology, $1972,13,394-403$.
TVERSKY, A. (Oregon Rsch. Inst., P.O. Box 3196, Eugene, Oreg. 97403). Elimination by aspects: A theory of choice. Psychological Review, 1972, 79, 281-299.

\section{SOCIAL PROCESSES}

GROTE, B. (Western Washington State Coll., Bellingham, Wash. 98225), \& CVETKOVICH, G. Humor appreciation and issue involvement. Psychonomic Science, 1972, 27, 199-200.

WIENER, M. (Clark Univ., Worcester, Mass. 01610), DEVOE, S., RUBINOW, S., \& GELLER, J. Nonverbal behavior and nonverbal communication. Psychological Review, 1972, 79, 185-214.

\section{ATTRACTION}

GOUAUX, C. (Univ. of Missouri, St. Louis, Mo. 63121). Increased attraction to stranger through neutralization of negative interpersonal affect by repeated evaluation. Psychonomic Science, 1972, 27, 101-102.

JOHNSON, D. W. (Univ. of Minnesota, Minneapolis, Minn. 55455), \& JOHNSON, $S$. The effects of attitude similarity, expectation of goal facilitation, and actual goal facilitation on interpersonal attraction. Journal of Experimental Social Psychology, 1972, 8, 197-206.

JONES, E. E. (Duke Univ., Durham, N.C. 27706), \& WEIN, G. A. Attitude similarity, expectancy violation, and attraction. Journal of Experimental Social Psychology, 1972, 8, 222-235.

McGINLEY, H. (Univ. of Wyoming, Laramie, Wyo. 82070), \& McGINLEY, P. Attraction toward a stranger as a function of direct and vicarious reinforcement. Journal of Experimental Research in Personality, 1972, 6, 60-68.

SHAW, J. I. (San Fernando Valley State Coll., Northridge, Calif. 91324). Reactions to victims and defendants of varying degrees of attractiveness. Psychonomic Science, 1972, 27, 329-330.

\section{ATTITUDES}

ANDERSON, N. H. (Univ. of California, San Diego, La Jolla, Calif. 92037), SAWYERS, B. K., \& FARKAS, A. J. President paragraphs. Behavior Research
Methods \& Instrumentation, 1972, 4, 177-192.

BLEDA, P. R. (1428 King Ave., Apt. 25, Columbus, Ohio 43212). Perception of height as a linear function of attitude similarity. Psychonomic Science, 1972, 27, 197-198.

BREED, G. (Univ. of South Dakota, Vermillion, S. Dak. 57069), \& PORTER, M. Eye contact, attitudes, and attitude change among males. Journal of Genetic Psychology, 1972, 120, 211-217.

BRYSON, J. B. (San Diego State Coll., San Diego, Calif. 92115). Relative influence of evaluative sign and evaluative dimensions in impression formation. Psychonomic Science, 1972, 27, 333-334.

JOHNSON, D. W. (Univ. of Minnesota, Minneapolis, Minn. 55455), \& JOHNSON, S. The effects of attitude similarity, expectation of goal facilitation, and actual goal facilitation on interpersonal attraction. Journal of Experimental Social Psychology, 1972, 8, 197-206.

JONES, E. E. (Duke Univ., Durham, N.C. 27706), \& WEIN, G. A. Attitude similarity, expectancy violation, and attraction. Journal of Experimental Social Psychology, 1972, 8, 222-235.

KIRBY, D. M. (Univ. of Western Ontario, London, Ont., Canada), \& GAR DNER, R. C. Ethnic stereotypes: Norms on 208 words typically used in their assessment. Canadian Journal of Psychology, 1972, 26, 140-154.

ZANNA, M. P. (Princeton Univ. Princeton, N.J. 08540), \& HAMILTON, D. L. Attribute dimensions and patterns of trait inferences. Psychonomic Science, $1972,27,353-354$.

\section{SOCIAL INFLUENCES}

CLARK, R. D., III. (Florida State Univ., Tallahassee, Fla. 32306), \& WILLEMS, E. P. TW o interpretations of Brown's hypothesis for the risky shift. Psychological Bulletin, 1972, 78, $62-63$.
GEEN, R. G. (Univ. of Missouri, Columbia, Mo, 65201), \& STONNER, D. The context of observed violence: Inhibition of aggression through displays of unsuccessful retaliation. Psychonomic Science, 1972, 27, 342-344

MACK, D. (Macalester Coll., St. Paul, Minn. 55105), \& KNIGHT, G. P. Information on the nature of the game as a determinant of behavior in the prisoner's dilemma. Psychonomic Science, 1972, 27, 99-100.

MORRISON, B. J. (Vice President \& Director of Consumer Rsch. Operations, Eshleman Co., 55 Public Sq., Cleveland, Ohio 44113), \& WALTERS, S. B. The placebo effect: I. Situational anxiety and model behavior. Psychonomic Science, 1972, 27, 80-82.

WARREN, V. L., \& CAIRNS, R. B. (Indiana Univ., Bloomington, Ind. 47401 ). Social reinforcement satiation: An outcome of frequency or ambiguity? Journal of Experimental Child Psychology, 1972, 13, 249-260.

\section{SOCIAL INTERACTION}

AIELLO, J. R. (Michigan State Univ., East Lansing, Mich. 48823). A test of equilibrium theory: Visual interaction in relation to orientation, distance and sex of interactants. Psychonomic Science, $1972,27,335-336$.

DORSKY, F. S. (Kent State Univ., Kent, Ohio 44244), \& TAYLOR, S. $P$. Physical aggression as a function of manifest anxiety. Psychonomic Science, 1972, 27, 103-104.

HARRIS, R. J. (Univ. of New Mexico, Albuquerque, N. Mex. 87106). An interval-scale classification system for all $2 \times 2$ games. Behavioral Science, 1972, 17, 371-383.

SHUNTICH, R. J. (Kent State Univ., Kent, Ohio 44240), \& TAYLOR, S. P. The effects of alcohol on human physical aggression. Journal of Experimental Research in Personality, 1972, 6, 34-38.

STEVENSON, M. B. (Michigan State Univ., East Lansing, Mich. 48823), \& PHILLIPS, J. L. Entrapment in $2 \times 2$ games with force vulnerable equilibria. Behavioral Science, 1972, $17,361 \cdot 370$.

STREUFERT, S. (Purdue Univ., Lafayette, Ind. 47907 ), CAFFERTY, T., \& CHERRY, F. Information load, group organization, and communication frequency. Psychonomic Science, $1972,27,348-350$. 